\title{
Beretning om Grundtvig-Selskabets virksomhed
}

Ved årsmødet den 8. september I96I i Vartov holdt bibliotekar fens A. Nielsen eftermiddagens foredrag om Grundtvig og greve C. C. S. DanneskioldSamsøe. Den indgående undersøgelse er siden trykt i Grundtvig-Studier I96 I, s. 7-78, og 1962, s. 7-52. Om aftenen talte formanden, domprovst Henning Hoirup i Vartov Kirke om »Grundtvig som forkynder« (trykt i Vartovbogen I96r, s. 53-73).

Årsmødet sendte hilsen til forstander Ernst 7. Borup, som kort efter - den I I. september - afgik ved døden. Fra februar I949 var han Selskabets virksomme næstformand. Som fremhævet i formandens mindeord (i GrundtvigStudier I96I, s. I I2 f.) vil Borup mindes for sin indsats ved indretningen af Grundtvig-Biblioteket i Vartov og for den praktiske organisation af GrundtvigSelskabets daglige arbejde. Vore årsmøder og medlemsmøder fik præg af hans rolige, hjertelige og vederheftige personlighed.

Overfor professor, dr. jur. Poul Andersen, der ikke ønskede genvalg til styrelsen, gav formanden udtryk for Selskabets taknemmelighed for hans værdifulde medvirken ved dets oprettelse, ved udarbejdelsen af love og ved støtte overfor bevilgende myndigheder. Nyvalgt til styrelsen blev docent, teol: dr: Harry Aronson, Lund, og universitetslektor Forgen Elbek, Århus. Som revisor nyvalgtes pastor Asger Due, København, i stedet for sekretær Alfred Dam.

»Grundtvig-Studier « I96I fremkom først mod årets slutning, omtrent samtidig med Skrifter udgivet af Grundtvig-Selskabet bind XII, lektor Sigurd Aa. Aarnes: Historieskrivning og livssyn hos Grundtvig (Universitetsforlaget BergenOslo, I96I). Denne værdifulde og heltigennem på kildeundersøgelser hvilende afhandling, som er den anden norske doktordisputats om Grundtvig, er blevet modtaget med stor interesse også i Danmark; ved forsvaret i Bergen i maj var professor, Dr. phil. Gustav Albeck og lektor, Dr. phil. William Michelsen til stede, sidstnævnte som anden opponent (oppositionen er trykt i GrundtvigStudier ig62, s. 53-86).

Arbejdet med Registrant over N. F. S. Grundtvigs Papirer er fortsat, takket være bevillinger fra Statens almindelige Videnskabsfond; indtil udgangen af I96I er anvendt $74.000 \mathrm{kr}$. (heri indbefattet publikationen af registranten), og arbejdet forventes afsluttet ved hjælp af en restbevilling på 7.I34 kr. Til udgivelsen af Grundtvig-Studier har Undervisningsministeriet ydet $2.000 \mathrm{kr}$.

Hvad mikrofotograferingen af Grundtvigs manuskripter angår, er det aftalt med rigsbibliotekaren, at Det kgl. Bibliotek selv i løbet af et par år vil søge skaffet de fornødne midler til at afslutte denne både for Det kgl. Bibliotek og Selskabet magtpåliggende opgave. På styrelsens vegne takker jeg rigsbibliotekar Palle Birkelund og bibliotekarerne Kåre Olsen og Tue Gad, som i samarbejde med Dr. phil. Helge Toldberg har ledet arbejdet. 
Fra biskop C. I. Scharlings arvinger har Grundtvig-Selskabet modtaget 200 eks. af bogen: »Grundtvig og Romantiken« (Gyldendal, I947) som gave. $\mathrm{Vi}$ er taknemmelige for overdragelsen og har vedtaget, at bogen tilbydes Selskabets medlemmer for så lav en pris som 7 kr. Indtægten tilfalder Magnus Stevns Mindefond, som ved udgangen af 196r havde en kapital på $3.177 \mathrm{kr}$. På museumsinspektør Povl Ellers bog: »N. F. S. Grundtvig-Portrætter« (1962) er opnået særpris for medlemmer.

Der indløb hilsen til årsmødet fra The Irish Folk School Council (der bl. a. sender irske lærere til Danmark på feriekurser) gennem vort styrelsesmedlem Dr. Noëlle Davies, der lige siden 1948 hvert år har udarbejdet de engelske resumeer til »Grundtvig-Studier $\ll$.

I anledning af planen om at nedlægge Udby Præstegård og henlægge Udby og Ørslev sogne til henholdsvis Sværdborg og Øster Egesborg har formanden rettet henvendelse til biskop Schiøler om, at Udby Præstegård bevares som præstebolig.

En brochure om Grundtvig-Selskabet, med fortegnelse over publikationer, er udsendt. Den fås frit ved henvendelse til Vartovs kontor, Farvergade 27, København K.

I anledning af I50-året for tilblivelsen af N. F. S. Grundtvigs digtning »Roskilde-Riim《 henlagde Grundtvig-Selskabet årsmodet 1962 til Roskilde. Historisk Samfund for Københavns Amt, hvis formand er Roskildes historiker, direktør Arthur Fang, deltog i tilrettelægningen og gennemførelsen af det indledende møde i Roskilde Domkirke om aftenen den 5. september, hvor over Ioo af de to foreningers medlemmer var mødt. Formanden bød velkommen, og domkirkens historiker, dr. 7. O. Arhnung, ledte ypperligt omvisningen, i samarbejde med dr. William Michelsen, som på de rette steder foredrog højdepunkter af Grundtvigs digt.

Ved otte-tiden var man nået op i Riddersalen over Hellig Tre Kongers Kapel, der ligesom i 1812 kun var sparsomt oplyst af levende lys. Her talte dr. Michelsen om »Roskilde-Riim «, ud fra undersøgelser af den ældste, aldrig trykte tekst, hvoraf et sammenhængende uddrag blev oplæst af professor, dr. Gustav Albeck. Denne vellykkede »gentagelse« af Grundtvigs bekendte fremførelse af digtet for landemodet (skildret af Daniel P. Smith, hvis erindringer herom er udgivet i Fra Københavns Amt 1954, s. 49 f.) kan man nu få et godt indtryk af, idet dr. Michelsen har besørget såvel Grundtvigs tekst som de indledende foredrag udgivet i Fra Københavns Amt 1962, s. 3-38. Grundtvig-Selskabet takker såvel Historisk Samfund for Københavns Amt samt domprovst, dr. Østergaard Nielsen og domkirkeværgen, udskrivningschef Madsen for velvillig bistand til genoplivelsen af den historiske aften under de bedst mulige vilkår.

Torsdag den 6. september talte dr. Sigurd Aa. Aarnes, Bergen, i Riddersalen om »Historieskrivning og livssyn hos den unge Grundtvig «. Efter at formanden havde takket dr. Aarnes for hans indsats i Grundtvig-forskningen, holdtes årsmødet med biskop Øllgaard som dirigent. Det vedtoges at forhøje 
kontingentet til $14 \mathrm{kr}$., for studenter dog kun til $8 \mathrm{kr}$. Dr. Aarnes nyvalgtes til styrelsen. På udflugten til Odsherred, hvori et halvt hundrede deltog, bedede man på opturen i Gundestrup Færgekro. Ved Odden Kirke blev vi modtaget af sognepræst Petri, og dr. Albeck talte ved mindesmærket med Grundtvigs indskrift over de faldne i slaget ved Sjællands Odde I808. I kirken fortalte formanden om Johan Grundtvigs gerning i Odden Sogn fra 1766 til 1776. Hjemturen gik over Nykøbing (Mindetavlen for slægten Grundtvig) og Annebjerggård til Egebjerg, hvor sognepræst Bjerager og frue med stor gæstfrihed bød deltagerne til kaffebordene. I Egebjerg Kirke talte formanden om Grundtvigs moder, og derefter gik man til barndomshjemmet, Egebjerggård med Niels Skovgaards mindesten (hugget af Niels Larsen Stevns), og ejerinden, fru Andersen, bød deltagerne indenfor i det gamle stuehus fra 1680 .

Omkring I. oktober udkom, under redaktion af dr. Albeck, GrundtvigStudier 1962 - den femtende årgang. Samtidig udgik forudbestillingstilbud på Erica Simon: De l'Union culturelle du Nord (fransk oversættelse med kommentar af Grundtvigs »Om Nordens videnskabelige Forening «. G. E. G. Gad, 1962), Erik Heinemeier: Grundtvigs menneskesyn (H. Hirschsprung, 1962) og foakim Skovgaard: Minder fra barndom og ungdom, udgivet af Henning Høirup (Skovgaard-Museet, Viborg, 1962).

I oktober udsendte Selskabet i samarbejde med Det danske Sprog- og Litteraturselskab tre bind af Registrant over N.F.S. Grundtvigs Papirer, nemlig bd. XXIII (fascikel 400-405), bd. XXV (fasc. 483-514) og bd. XXVI (fasc. $5^{1} 5^{-565}$ og andre samlinger). Senere fulgte bd. XXVII (Andre Samlinger) og med bd. XXVIII (Andre samlinger), udsendt i februar 1963 , var arbejdet med registreringen af de i Grundtvig-arkivet og andre samlinger i Det kgl. Bibliotek foreliggende Grundtvig-manuskripter ført til ende. Det omfattende værk vil blive afsluttet med et eller to bind indeholdende emne- og personregistre til registranten; disse forventes udsendt i foråret 1964 .

I 1962 har Grundtvig-Selskabet som de foregående år modtaget $2.000 \mathrm{kr}$. i tilskud til udgivelsen af Grundtvig-Studier fra Undervisningsministeriet og derudover yderligere $2.000 \mathrm{kr}$. fra Carlsen-Langes Legatstiftelse samt - som eengangsbevilling - et tilskud fra Kirkeligt Samfund på 2.00o kr. - Magnus Stevns Mindefond havde ved udgangen af 1962 en kapital på $3.709 \mathrm{kr}$.

Selskabet har $\mathrm{i}$ årets løb ydet bistand bl. a. til pastor Young Whan Kim, Seoul, Korea, der har udgivet to skrifter om Grundtvig og Danmark i sit hjemland, og nu, under studier i Danmark, har forberedt en folkelig koreansk sangbog med oversættelser af salmer og sange især af Grundtvig. Selskabets sekretær, pastor Valdemar Nielsen, har rådgivet med udvalget.

Henning Hoirup. 